\title{
INTERACTIONAL FAIRNESS AS A MEDIATOR BETWEEN MERIT-BASED PAY MANAGEMENT AND ORGANIZATIONAL COMMITMENT
}

\author{
Mohd Ridwan bin Abd Razak ${ }^{1^{*}}$ and Enah binti Ali \\ ${ }^{1}$ Faculty of Management and Economics, Universiti Pendidikan Sultan Idris, Malaysia. \\ ${ }^{2}$ Education Policy Planning and Research Division, Ministry of Education, Malaysia.
}

\begin{abstract}
The purpose of this quantitative study was to evaluate the ability of interactional fairness as a mediator in the relationship between merit-based pay management (such as communication and performance assessment) and organizational commitment. A cross-sectional technique was used to collect 450 useable data of workers from a government-linked company (GLC), who had served more than five years in Selangor and Kuala Lumpur. The outcomes of the Partial Least Square Structural Equation Modelling (PLS-SEM) path model analysis indicated three important findings. First, communication and performance assessment was significantly correlated with interactional fairness. Second, interactional fairness was significantly correlated with organizational commitment. Third, communication, performance assessment and interactional fairness were significantly correlated with organizational commitment. Statistically, the findings of this study verified that the relationship between communication and performance assessment with organizational commitment is indirectly influenced by interactional fairness. These findings would benefit researchers and organizational management to recognize the importance of merit-based pay management (communication and performance assessment) to nurture employees' positive feelings, behaviors, and attitudes in an organization. An effective pay management system would likely improve employees' morale and enhance organizational competitiveness in facing the challenges of the COVID-19 pandemic.
\end{abstract}

Keywords: communication, interactional fairness, merit-based pay management, organizational commitment, performance assessment

\section{ARTICLE INFO}

\section{Article History:}

Received: 6 January 2021

Accepted: 15 March 2021

Published: 30 April 2021

- Corresponding Author: Mohd Ridwan bin Abd Razak. E-mail: mridwan@fpe.upsi.edu.my 


\section{INTRODUCTION}

Pay management is an important topic in the organizational management domain. Generally, pay refers to any monetary payment given to the workers as an exchange for work done (Novarini \& Imbayani, 2019; Oke et al., 2017). Meanwhile, based on the organizational perspective, pay refers to the payment allocated to workers with the objectives to attract, retain and motivate competent workers in the organization (Mabaso \& Dlamini, 2018; Korir \& Kipkebut, 2016). Therefore, pay is not just a mechanism to compensate workers, but it is also a strategy to enhance organizational productivity through strong support from competent workers.

The selection of pay systems by the organization is based on and organization's strategies and objectives (Khan \& Khan, 2017; Priya \& Sudhamathi, 2019). For the organization that operates in the domestic market and with low competition, they are more likely to implement jobbased pay system. In this pay system, the amount, type, and level of pay are determined by seniority, job function, and length of service (Martocchio, 2016; Newman et al., 2017). Although the implementation of this pay system is still relevant, many scholars such as Levi et al. (2018) and Messersmith et al. (2018) argue that it is unable to retain, attract and motivate competent workers in the organization. Whereas, for the organization that operates in the global market with high competition, they are more likely to choose a merit-based pay system. Within this pay system, the amount, type, and level of pay is determined based on a worker's productivity (Abd Razak et al., 2018; Harada, 2019). In-depth analysis of the literature has revealed that there are two dimensions of merit-based pay. First, pay for individual performance (e.g. annual bonus, annual increment, and incentives). Second, pay for group performance (e.g. gain-sharing and group-based incentives) (Mayes et al., 2017; Načinović Braje et al., 2019).

The ability of a merit-based pay system to enhance organizational productivity and competitiveness has attracted many organizations to implement this pay system. According to Kato and Kodama (2015), the implementation of the merit-based pay system has increased worker's productivity from $26 \%$ to $30 \%$. Furthermore, studies by Rajaratnam (2020) and Song et al. (2020) proved that the implementation of meritbased pay may help to enhance organizational financial and non-financial 
performance. Based on the undeniable evidence above, it strongly proven that the implementation of a merit-based pay system may help organizations to enhance their productivity and competitiveness in a borderless business world.

In-depth analysis of the studied organization found that there are several issues related to employee's commitment and performance. For example, a majority of newly hired postman only lasted working for 3 months and often complained of workload that is not commensurate with the pay received. Both of these issues arise as a result of weaknesses in pay management (Fauzan, 2018; Hasniza, 2018). To overcome these issues, the studied organization needs to strengthen the pay management system to a fairer one. The effectiveness of a pay management system may help to increase organizational competitiveness in the era of the Industrial Revolution 4.0 (Damiani et al., 2016)

Additionally, analysis of the literature about merit-based pay management found that many studies have been done to explore the relationship between merit-based pay and organizational commitment. However, largely unknown and unclear until now is the role of interactional fairness as a mediating variable in the particular relationship (Lee \& Chui, 2019; Abd Razak et al., 2019). This deficiency is due to previous studies using distributive and procedural fairness as a mediating variable in the relationship. This phenomenon has overlooked the role of interactional fairness as one of the important components in the organizational fairness domain (Mylona \& Mihail, 2019; Paoline et al., 2018). Therefore, the objective of this study was to evaluate the effect of interactional fairness as a mediating variable in the relationship between merit-based pay management and organizational commitment.

\section{LITERATURE REVIEW}

\section{Merit-based Pay Management}

Merit-based pay management is an important topic in the organizational pay management domain. In the organizational pay management perspective, merit-based pay management refers to a systematic method 
used by an organization to allocate fair pay based on worker's actual productivity (Harada, 2019; Simpson et al., 2020). There are two important components in the merit-based pay management, which are communication and performance assessment (Brownson \& Fowler, 2020; Ismail, 2020). Communication broadly refers to the sharing of information between organization and workers regarding the implementation of merit-based pay (such as type of pay, the method to determine pay level, and the amount of pay) (Jean et al., 2019; Marasi et al., 2018). The readiness of organizations to practice openness in communication may provide a clear picture about the advantages of a merit-based pay system, provide sufficient and correct information about the relationship between merit-based pay and performance, and enhance worker's understanding and enhance the credibility of the pay system (Jean et al., 2019; Marasi et al., 2018). Whereas, performance assessment refers to the formal and fair method to assess worker's actual productivity based on specific standards and criteria set by the organization (Islami et al., 2018; Setiawati \& Ariani, 2020). In merit-based pay management, performance assessment outcomes will be used as a guideline for making fair pay allocation to workers (Abd Razak et al., 2019; Ismail, 2020).

\section{Interactional Fairness}

Interactional fairness is an important component of the organizational justice domain. Interactional fairness is broadly elaborated as a feeling of fairness among the workers when they are treated fairly (with politeness, sincerity, respect, accountability, and dignity) by the immediate supervisor (Chang et al., 2020; Vajda, 2019). When the worker perceives that he/she is treated accordingly by the immediate supervisor, they are more likely to have a high-level of the feeling of fairness. While the worker who perceives that they are not treated accordingly will have a low-level feeling of fairness (Holmvall et al., 2019; Van Dijke et al., 2019). Therefore, it is very crucial for the organization to ensure that all levels and categories of workers are treated accordingly.

\section{Organizational Commitment}

The importance of organizational commitment has been recognized by prominent scholars in the field of organizational behavior. Organizational 
commitment can be explained as a strong emotional attachment to the organization that can motivate the workers to strongly support organizational strategies and objectives (Chen et al., 2019; Liggans et al., 2019). In-depth analysis of the organizational behavior research literature has indicated that organizational commitment consists of three important dimensions, which are affective commitment, continuance commitment, and normative commitment (Sufian \& Lee, 2019; Abdin et al., 2019). Affective commitment refers to a strong emotional bonding between workers and his/her organization that invokes the feeling of togetherness (Albrecht \& Marty, 2020; Odoardi et al., 2019). Further, continuance commitment refers to the worker's intention to remain with the organization because of financial and non-financial benefits enjoyed by the workers. In this situation, workers believe that the organization offers a range of unbeatable financial and nonfinancial benefits (Cohen \& Abd El Majid, 2020; Galanaki, 2019). Normative commitment refers to a sense of responsibility that causes the workers to feel that it is his/her obligation to provide strong support and commitment to the organization (Nguyen \& Tu, 2020; Sungu et al., 2020). A majority scholars such as Santos (2020), and Yusuf (2020) have proven that if the workers obtain a sufficient degree of affective commitment, continuance commitment, and normative commitment, it will invoke the worker's sense of loyalty to the organization.

\section{HYPOTHESES DEVELOPMENT}

\section{The Relationship between Merit-Based Pay Management and Interactional Fairness}

The relationship between merit-based pay management and interactional fairness is consistent with the idea of the Leader-Member Exchange Theory by Dansereau et al. (1975). This theory suggests that a good relationship (based on ethical, respect, dignity, openness, accountability, and honesty) between an immediate supervisor and his/her subordinate will strongly invoke the feeling of fairness among workers in an organization. The idea of this theory obtained intense support from many scholars such as Heffernan and Dundon (2016) and Abd Razak et al. (2019). Many studies have been done to evaluate the relationship between meritbased pay management and interactional fairness. However, the findings are 
not consistent. For example, the study conducted by Roth (2006) and Kepes et al. (2009). These studies found that the management of merit-based pay is unable to invoke a feeling of interactional fairness. This phenomenon occurred due to the misleading financial information shared between an organization and the workers (i.e., accounts of arbitrariness, accounts of misinformation, and accounts of discrimination) (Roth, 2006). Furthermore, even though the worker's pay is determined based on performance, the determination of worker's pay is influenced by politics in the organization (Kepes et al., 2009). Studies conducted by Heffernan and Dundon (2016) and Abd Razak et al. (2019) found that the willingness of the organization to openly share information about the method used to determine type, level, and/or amount of pay allocated to workers and the ability of an organization to conduct a fair performance assessment, and use the outcomes of the performance assessment as a guideline to determine fair pay to the workers may improve a worker's perception on interactional fairness. Due to the inconsistent findings, the hypotheses for this study were:

H1: Communication is significantly correlated with interactional fairness.

H2: Performance assessment is significantly correlated with interactional fairness.

\section{Relationship between Interactional Fairness and Organizational Commitment}

The relationship between interactional fairness and organizational commitment is consistent with the idea of the Equity Theory by Adams (1963). This theory suggests that fair treatment from immediate supervisors to the workers is an important element to nurture a feeling of fairness in the organization. Related to this situation, fair interpersonal treatment between supervisors and subordinates may improve a worker's commitment to the organization. The idea of this theory obtained intense support from many scholars such as Jami'iaturochmah et al. (2019), and Abdin et al. (2019). An analysis of the previous literature shows inconsistent findings in the relationship between interactional fairness and organizational commitment. For example, the studies conducted by Indahyati and Sintaasih (2019) and Saleem et al. (2018). These studies found that worker's perception on interactional fairness is unable to improve the level of a worker's commitment to the organization. This phenomenon occurred due to the decisions made 
by the organization being strongly influenced by organizational politics (Indahyati \& Sintaasih, 2019) and more likely to ignore a worker's rights and interests (Saleem et al., 2018). Meanwhile, the studies conducted by Jami' iaturochmah et al. (2019), and Abdin et al. (2019) found that the ability of an organization to provide fair interpersonal treatment to the worker may strongly improve a worker's commitment to support organizational strategies and objectives. These findings prove that interactional fairness plays an important role as a predictor of organizational commitment. Due to the inconsistent findings, the third hypothesis for this study was:

H3: Interactional fairness is significantly correlated with organizational commitment.

\section{The Relationship between Merit-based Pay Management, Interactional Fairness, and Organizational Commitment}

The role of interactional fairness as a mediating variable in the relationship between merit-based pay management and organizational commitment is in line with the idea of the Interactional Justice Theory by Bies and Moag (1986). This theory explains that the relationship between merit-based pay management and organizational commitment is established through interactional fairness. The ability of an organization to manage the merit-based pay system efficiently may invoke the feeling of interactional fairness. Further, it may enhance organizational commitment. The essence of this theory gained strong support from several scholars such as Abd Razak et al. (2019) and Heffernan and Dundon (2016). These studies indicated that the willingness of the organization to practice good communication and fair performance assessment will help to invoke a worker's feelings of interactional fairness. Further, this situation will help to enhance organizational commitment. Therefore, the fourth and fifth hypotheses for this study were:

H4: Communication and interactional fairness is significantly correlated with organizational commitment.

H5: Performance assessment and interactional fairness is significantly correlated with organizational commitment. 
Based on the idea of the theories and previous findings, the research framework for this study is exhibited in Figure 1.

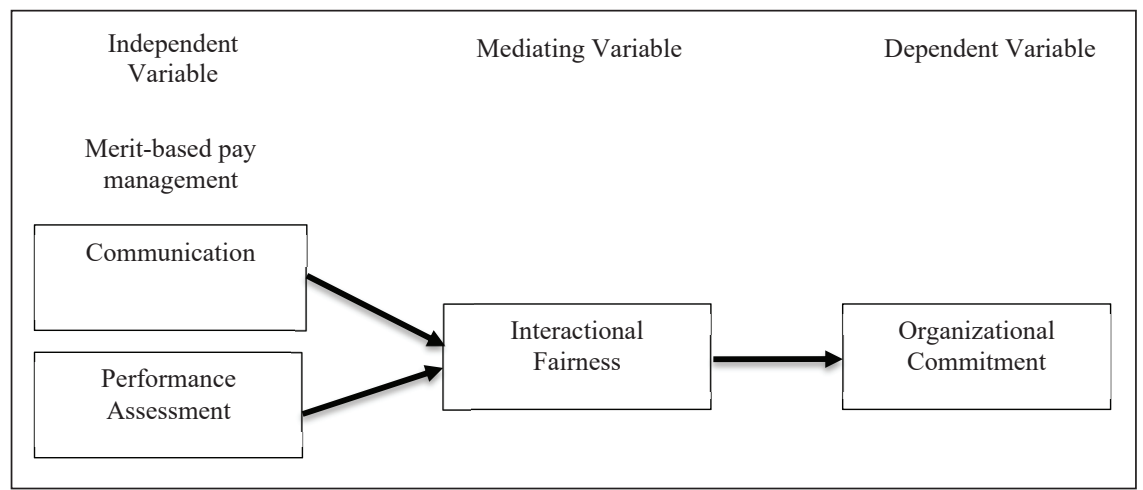

Figure 1: Research Framework

\section{METHODOLOGY}

\section{Research Design}

This study employed a cross-sectional research design. There are several advantages in using this strategy, such as improving data accuracy, reducing the bias of the data, and improving the quality of the data (Creswell, 2014; Lomand 2016; Sekaran \& Bougie, 2016). This study was performed at the largest postal service provider company in Malaysia. Due to confidentiality purposes, the name of the company is kept anonymously. The survey questionnaire used in this study was developed based on the previous merit-based pay literature. Further, the questionnaire underwent back-to-back (English language - Malay language - English language) translation processes. This strategy was to make sure that the findings of this study meet the high standards of validity and reliability (Creswell, 2014; Lomand, 2016; Sekaran \& Bougie, 2016).

\section{Measures}

The survey questionnaire in this study consisted of three main sections. First, merit-based pay management was assessed using 21 items (with a combination of two main components, namely communication and 
performance assessment). Communication was assessed using 10 items and performance assessment was assessed using 11 items. All items were adapted from the merit-based pay management literature (Ismail et al., 2014; Marasi, 2014). Second, interactional fairness was assessed using six items, adapted from the interactional fairness literature (Colquitt \& Rodell, 2011). Third, organizational commitment was assessed using 14 items, adapted from the organizational behavior literature (Maqsood et al., 2012; Jaros, 2007). All items were assessed using a Likert-scale with a 7-item scales stretching from from "strongly disagree" (1) to "strongly agree" (7). Demographic variables were used as a control variable because this study dealt with worker's behavior.

\section{Sample}

The population of this study was 3,274 workers of a GLC at Selangor and Kuala Lumpur. The purposive sampling technique was used to distribute survey questionnaires to all levels and categories of workers' who had served more than five years in the organization. There were two main reasons why the researchers decided to utilize this sampling technique. First, the organization was unable to provide a list of registered workers due to confidentiality. Pursuant to this situation, it did not permit the researchers to use a random sampling technique. Second, was to collect accurate, valid, and reliable data for this study. Therefore, workers with more than five years of work experience in the organization were chosen because they are experienced, understood, and familiar with the implementation of a merit-based pay system. From the distributed survey questionnaires, only 450 usable questionnaires were returned to the researchers. According to the Raosoft sample size calculator, the total sample size for this study was 344. Therefore, 450 sample used in this study met the required standard. The survey questionnaires were answered by the respondents based on their consent and on a voluntary basis.

\section{Data Analysis}

The SmartPLS 3.0 was used to evaluate the validity and reliability of the instrument and test the study hypotheses. There were several reasons for the use the SmartPLS in this study. For example, it provided latent variable scores, prevented small sample size problems, assessed every 
complex model with many latent and manifest variables, hassled stringent assumptions about the distribution of variables and error terms, and handled both reflective and formative measurement models (Hair et al., 2017). The SmartPLS path model was used to evaluate the path coefficients for the structural model utilizing the standardized beta $(\beta)$ and $t$ statistics. The value $\mathrm{R}^{2}$ was used as an indicator of the overall predictive strength of the model.

\section{RESULTS}

\section{Respondent's Characteristics}

A majority of the respondents were male (84.2\%), married (87.1\%), working at branch office (70.9\%), Malaysia Education Certificate holders (74.4\%), permanent workers (98.9\%), aged between 25 to 34 years old (46.7\%), non-executive worker (78.4\%), working experience between 5 to 14 years (62.7\%), monthly income below RM2000 (44.4\%), and monthly expenses below RM2000 (43.8\%).

\section{Constructs Validity and Reliability Analysis}

Table 1 displays the results of the convergent validity and reliability analysis using factors loadings and average variance extracted (AVE). The values of factors loading for all items in this study were larger than 0.70 and the values of AVE for all constructs were larger than 0.5 . This indicated that all items and constructs used in this study had met the standard of convergent validity and reliability (Barclay et al., 1995; Hair et al., 2017; Henseler et al., 2009). The values of composite reliability for all constructs were larger than 0.70 . This situation indicated that all constructs used in this study had high internal consistency (Hair et al., 2017; Sekaran \& Bougie, 2016). 
Interactional Fairness as a Mediator Between Merit-Based Pay Management

Table 1: The Results of Convergent Validity and Reliability Analysis

\begin{tabular}{|c|c|c|c|c|c|c|}
\hline Constructs & Comm & PeAs & InFa & OrCo & AVE & $\begin{array}{l}\text { Composite } \\
\text { Reliability }\end{array}$ \\
\hline Communication & & & & & 0.636 & 0.946 \\
\hline Comm 1 & 0.821 & & & & & \\
\hline Comm 2 & 0.847 & & & & & \\
\hline Comm 3 & 0.841 & & & & & \\
\hline Comm 4 & 0.782 & & & & & \\
\hline Comm 5 & 0.842 & & & & & \\
\hline Comm 6 & 0.773 & & & & & \\
\hline Comm 7 & 0.780 & & & & & \\
\hline Comm 8 & 0.760 & & & & & \\
\hline Comm 9 & 0.775 & & & & & \\
\hline Comm 10 & 0.748 & & & & & \\
\hline Performance Assessment & & & & & 0.673 & 0.958 \\
\hline PeAs 1 & & 0.796 & & & & \\
\hline PeAs 2 & & 0.803 & & & & \\
\hline PeAs 3 & & 0.791 & & & & \\
\hline PeAs 4 & & 0.801 & & & & \\
\hline PeAs 5 & & 0.869 & & & & \\
\hline PeAs 6 & & 0.773 & & & & \\
\hline PeAs 7 & & 0.828 & & & & \\
\hline PeAs 8 & & 0.868 & & & & \\
\hline PeAs 9 & & 0.850 & & & & \\
\hline PeAs 10 & & 0.849 & & & & \\
\hline PeAs 11 & & 0.791 & & & & \\
\hline Interactional Fairness & & & & & 0.774 & 0.954 \\
\hline InFa1 & & & 0.836 & & & \\
\hline InFa 2 & & & 0.882 & & & \\
\hline InFa 3 & & & 0.897 & & & \\
\hline InFa 4 & & & 0.907 & & & \\
\hline InFa 5 & & & 0.908 & & & \\
\hline InFa 6 & & & 0.846 & & & \\
\hline Organizational Commitment & & & & & 0.663 & 0.965 \\
\hline OrCo 1 & & & & 0.855 & & \\
\hline OrCo 2 & & & & 0.843 & & \\
\hline OrCo 3 & & & & 0.877 & & \\
\hline OrCo 4 & & & & 0.715 & & \\
\hline OrCo 5 & & & & 0.845 & & \\
\hline OrCo 6 & & & & 0.819 & & \\
\hline OrCo 7 & & & & 0.864 & & \\
\hline OrCo 8 & & & & 0.716 & & \\
\hline
\end{tabular}




\begin{tabular}{|c|c|c|c|c|c|c|}
\hline Constructs & Comm & PeAs & InFa & OrCo & AVE & $\begin{array}{l}\text { Composite } \\
\text { Reliability }\end{array}$ \\
\hline OrCo 9 & & & & 0.814 & & \\
\hline OrCo 10 & & & & 0.727 & & \\
\hline OrCo 11 & & & & 0.807 & & \\
\hline OrCo 12 & & & & 0.793 & & \\
\hline OrCo 13 & & & & 0.841 & & \\
\hline OrCo 14 & & & & 0.862 & & \\
\hline
\end{tabular}

Table 2 displays the results of discriminant validity and reliability analysis using the Heterotrait-monotrait (HTMT). The values of HTMT for all constructs were less than 0.90 . This situation indicated that all constructs used in this study had met the standard of discriminant validity and reliability (Barclay et al., 1995; Hair et al., 2017; Henseler et al., 2009).

Table 2: The Results of Heterotrait-Monotrait (HTMT)

\begin{tabular}{|c|c|c|c|c|}
\hline Constructs & Communication & $\begin{array}{l}\text { Performance } \\
\text { Assessment }\end{array}$ & $\begin{array}{l}\text { Interactional } \\
\text { Fairness }\end{array}$ & $\begin{array}{c}\text { Organizational } \\
\text { Commitment }\end{array}$ \\
\hline \multicolumn{5}{|l|}{ Communication } \\
\hline $\begin{array}{l}\text { Performance } \\
\text { Assessment }\end{array}$ & 0.626 & & & \\
\hline Interactional Fairness & 0.650 & 0.786 & & \\
\hline $\begin{array}{l}\text { Organizational } \\
\text { Commitment }\end{array}$ & 0.594 & 0.526 & 0.457 & \\
\hline
\end{tabular}

Table 3 displays the results of descriptive statistic and variance inflation factors analysis. The mean values for all constructs were between 5.3327 and 5.5192. This situation showed that the majority of the respondents believed that the levels of communication, performance assessment, interactional fairness, and organizational commitment were high (5) and very high (7). While the values of VIF for the relationship between the independent variables (i.e., communication and performance assessment), mediating variable (i.e., interactional fairness), and dependent variable (i.e., organizational commitment) were less than 5.0. This situation proved that the data used in this study was free from serious collinearity problems (Hair et al., 2017). 
Table 3: The Results of Descriptive Statistic and Variance Inflation Factors Analysis

\begin{tabular}{lcccccc}
\hline \multirow{2}{*}{ Constructs } & Mean & \multirow{2}{*}{$\begin{array}{c}\text { Standard } \\
\text { Deviation }\end{array}$} & & \multicolumn{3}{c}{$\begin{array}{c}\text { Variance Inflation Factors } \\
\text { (VIF) }\end{array}$} \\
& & & $\mathbf{1}$ & $\mathbf{2}$ & $\mathbf{3}$ & $\mathbf{4}$ \\
\hline Communication & 5.3327 & .64281 & & & 1.540 & \\
Performance Assessment & 5.5192 & .69407 & & & 1.540 & \\
Interactional Fairness & 5.4570 & .70272 & & & & 1.000 \\
Organizational Commitment & 5.4429 & .73849 & & & & \\
\hline
\end{tabular}

\section{Results of Testing Hypothesis 1, 2 and 3}

Table 4 displays the results of testing the direct effects model. The presence of communication and performance assessment in the analysis contributed 60.5 percent of the variance in interactional fairness. This result proves that the overall predictive strength of the model was substantial effect (Cohen, 1988). While the presence of interactional fairness in the analysis contributed 20 percent of the variance in organizational commitment. This result proves that the overall predictive strength of the model was moderate effect (Cohen, 1988). Further, the results of testing the direct effects model showed three important findings. First, communication was significantly correlated with interactional fairness $(\beta=0.276 ; \mathrm{t}=2.696)$, therefore hypothesis 1 was accepted. Second, performance assessment was significantly correlated with interactional fairness $(\beta=0.582 ; \mathrm{t}=5.425)$, therefore hypothesis 2 was accepted. Third, interactional fairness was significantly correlated with organizational commitment $(\beta=0.447 ; \mathrm{t}=$ 6.018), therefore hypothesis 3 was accepted. In sum, these results indicated that communication and performance assessment are important predictors of interactional fairness and interactional fairness plays is an important predictor of organizational commitment in the organization.

Table 4: The Results of Testing the Hypotheses 1, 2 and 3

\begin{tabular}{llcccc}
\hline & Path & $\beta$ Values & $t$-Values & $\boldsymbol{R}^{2}$ & Decision \\
\hline $\mathrm{H}_{1}$ & $\begin{array}{l}\text { Communication } \rightarrow \text { Interactional } \\
\text { fairness }\end{array}$ & 0.276 & 2.696 & 0.605 & Accepted \\
$\mathrm{H}_{2}$ & $\begin{array}{l}\text { Performance assessment } \rightarrow \\
\text { Interactional fairness }\end{array}$ & 0.582 & 5.425 & 0.605 & Accepted \\
$\mathrm{H}_{3} \quad \begin{array}{l}\text { Interactional fairness } \rightarrow \\
\text { Organizational commitment }\end{array}$ & 0.447 & 6.018 & 0.200 & Accepted \\
\hline
\end{tabular}




\section{Result of Testing Hypothesis 4 and 5}

Table 5 displays the results of testing the indirect effects model. The presence of communication, performance assessment, and interactional fairness in the analysis contributed 20 percent of the variance in organizational commitment. This result proved that the overall predictive strength of the model was moderate effect (Cohen, 1988). Further, the results of testing the indirect effects model showed two important findings. First, communication and interactional fairness was significantly correlated with organizational commitment $(\beta=0.123 ; \mathrm{t}=2.358)$, therefore hypothesis 4 was accepted. Second, performance assessment and interactional fairness was significantly correlated with organizational commitment $(\beta=0.260 ; \mathrm{t}=$ $3.844)$, therefore hypothesis 5 was accepted. In sum, these results indicated that interactional fairness acted as an important mediating variable in the relationship between merit-based pay management and organizational commitment in the organization.

Table 5: The Results of Testing the Hypotheses 4 and 5

\begin{tabular}{clcccc}
\hline Path & $\boldsymbol{\beta}$ Values & $\mathrm{t}$-Values & $\boldsymbol{R}^{2}$ & Decision \\
\hline $\mathrm{H}_{4}$ & $\begin{array}{l}\text { Communication } \rightarrow \text { Interactional } \\
\text { fairness } \rightarrow \text { Organizational } \\
\text { commitment }\end{array}$ & 0.123 & 2.358 & 0.200 & Accepted \\
$\mathrm{H}_{5} \quad \begin{array}{l}\text { Performance assessment } \\
\rightarrow \text { Interactional fairness } \rightarrow \\
\text { Organizational commitment }\end{array}$ & 0.260 & 3.844 & 0.200 & Accepted \\
\hline Note: significant at t-value $>1.96$ & & & & &
\end{tabular}

An extension analysis to identify the types of mediating variables was conducted using the procedure suggested by Hair et al. (2017) and Zhao et al. (2010). The analysis of direct effect models (interdependence between communication and interactional fairness, interdependence between performance assessment and interactional fairness, interdependence between interactional fairness organizational commitment, interdependence between communication and organizational commitment, interdependence between performance assessment and organizational commitment) and analysis of indirect effect models (interdependence between communication, interactional fairness and organizational commitment and interdependence between performance assessment, interactional fairness and organizational commitment) found them to be significantly correlated. Therefore, this outcome showed that interactional fairness acts as a mediating variable 
that is categorized as a competitive mediation type (Hair et al., 2017; Zhao et al., 2010).

\section{DISCUSSION}

The outcome of this study proved that the relationship between merit-based pay management and interactional fairness had improved organizational commitment. Pursuant to this outcome, the organizational management team (especially related to the human resource management) have to strengthen and improve their internal and external capacity in managing merit-based pay systems in line with the organization's and worker's interests. Most of the workers in the organization perceived that the degree of communication, performance assessment, interactional fairness, and organizational commitment were high. This phenomenon clarified that the acuity of an organization's pay management team to aptly practice the best communication style and conduct a fair performance assessment will induce the worker's feeling of interactional fairness. This feeling will thus improve worker's commitment to the organization.

This study has contributed to three important aspects which are contribution to theory, research methodology, and practice. From a theoretical perspective, this study affords two important and specific outcomes. First, the relationship between communication and organizational commitment is mediated by interactional fairness. Second, relationship between performance assessment and organizational commitment is mediated by interactional fairness. The outcomes are coherent with the essence of the Interactional Justice Theory by Bies and Moag (1986). This theory describes that the ability of organization's management team to disseminate information about the implementation of merit-based pay system accurately and sufficiently, actively acquire suggestions and feedbacks from workers, conduct fair performance assessment, and use performance assessment outcome as a guideline to determine a worker's pay will nurture a feeling of interactional fairness among workers. Further, it may improve a worker's commitment to the organization.

While from a research methodology perspective, the survey questionnaire used in this study had met the acceptable standards of validity 
and reliability analyses. Additionally, this study used a purposive sampling technique (only for employees who had served more than five years in the studied organization) to ensure that all the information given by the respondents are valid and reliable. This group of respondents considered has experience and knowledge about the implementation of merit-based pay in the organization. Therefore, it is capable to produce valid and reliable study outcomes.

Additionally, from a practical perspective, the outcomes of this study can be utilized by the organization to enhance the effectiveness of meritbased pay management. There are several important points that need to be given strong attention by the organization towards achieving the ultimate objectives of this pay system. First, determination of a worker's pay should be relooked accordingly to motivate and retain high performing workers in achieving an organization's objectives. Second, the adequacy of pay also should be considered in reflecting on new job challenges and expectations. Third, implementation of performance assessment should be based on fairness and equity, in terms of the measurement criterion, provision of assessment scores, and assessment guidelines. This element is very crucial because it may influence pay allocation to the workers directly as well as worker's standards of living, life satisfaction, statuses, and pro-social behavior in society. Fourth, as an enrichment to the organization's pay system, organizations are advised to implement combinations of merit-based pay based on individual and group performance. This move will promote teamwork among workers in the different levels and hierarchies in the organization. Consequently, it may enhance an organization's productivity, competitiveness, and reputation in the global market. Therefore, if these recommendations are strongly deliberated it may improve worker's commitment to intensely support the organization's merit-based pay system goals.

This study has several limitations. First, this study employed a crosssectional research design. Therefore, this study may not capture causal connections between the variables of interest. Second, the sample of this study was limited to employees of a GLC. Thus, the generalization of this study findings to other organizations is very limited. Third, this study only used interactional fairness as a mediating variable without considering procedural and/or distributive fairness as a mediating variable. The findings 
may differ if procedural and/or distributive fairness variable were adopted. If these limitations are strongly considered, a better finding may be discovered by future research.

There are several suggestions to improves the findings of future research. First, a longitudinal research design should be used to collect the data and describe the patterns of change and the direction and magnitude of causal relationships amongst variables of interest. Second, to fully understand the correlation between merit-based pay management, interactional fairness, and organizational commitment, more diverse organizations need to be involved. Third, other specific elements of organizational justice such as procedural and distributive fairness need to be considered as a mediating variable to explain the correlation between dependence and independent variables. The importance of these issues needs to be further explored in future studies.

\section{CONCLUSION}

In sum, the survey questionnaire used in this study had fulfilled the satisfactory standard of validity and reliability analyses. The outcomes of this study exposed that the relationship between merit-based pay management (i.e., communication and performance assessment) and interactional fairness is able to improve organizational commitment in the studied organization. Therefore, future studies and practice about an organizations pay system need to emphasize on the element of interactional fairness as a critical element in the merit-based pay management domain. This study indicated that the ability of immediate supervisors to properly implement communication and performance assessment will strongly improve a worker's commitment towards an organization. Consequently, this situation may help to improve organizational efficiency and effectiveness in this era of global competition.

\section{REFERENCES}

Abd Razak, M. R., Ismail, A., \& Ali, E. (2018). Performance based pay management as a determinant of procedural justice. Journal of Contemporary Issues and Thought, 8, 19-28. 
Abd Razak, M. R., Ismail, A., Ali, E., \& Nor, A. M. (2019). Perhubungan di antara komunikasi tentang ganjaran berasaskan prestasi, keadilan interaksi dan komitmen organisasi. Asian Journal of Accounting and Governance, 11, 109-122.

Abdin, F., Ismail, A., \& Mohamad, A. N. (2019). Trust in supervisor as a mediator of the relationship between perceived interactional fairness in reward systems and organizational commitment. The South East Asian Journal of Management, 13(2), 201-221.

Adams, J. S. (1963). Towards an understanding of inequity. The Journal of Abnormal and Social Psychology, 67(5), 422-436.

Albrecht, S. L., \& Marty, A. (2020). Personality, self-efficacy and job resources and their associations with employee engagement, affective commitment and turnover intentions. The International Journal of Human Resource Management, 31(5), 657-681.

Barclay, D., Higgins, C. \& Thompson, R. (1995). The Partial Least Squares (PLS) approach to causal modeling: Personal computer adoption and use as an illustration. Technology Study, 2(2), 285-309.

Bies, R. J., \& Moag, J. S. (1986). Interactional justice: Communication criteria of fairness. In R. J. Lewicki, B. H. Sheppard \& M. H. Bazerman (Eds.), Research on Negotiation in Organizations (pp. 43-55). Greenwich: JAI Press.

Brownson, K., \& Fowler, L. (2020). Evaluating how we evaluate success: Monitoring, evaluation and adaptive management in Payments for Watershed Services programs. Land Use Policy, 94, 104505.

Chang, H., Son, S. Y., \& Pak, J. (2020). How do leader-member interactions influence the HRM-performance relationship? A multiple exchange perspective. Human Performance, 33(4), 282-301.

Chen, Y., Zhou, X., \& Klyver, K. (2019). Collective efficacy: Linking paternalistic leadership to organizational commitment. Journal of Business Ethics, 159(2), 587-603. 
Cohen, A., \& Abd El Majid, I. (2020). The role of principals' values and leadership styles in developing organisational commitment among Arab teachers in Israel. International Journal of Human Resources Development and Management, 20(3/4), 212-230.

Cohen, J. (1988). Statistical power analysis for the behavioural sciences. Hillsdale, NJ: Erlbaum.

Colquitt, J. A., \& Rodell, J. B. (2011). Justice, trust, and trustworthiness: A longitudinal analysis integrating three theoretical perspectives. Academy of Management Journal, 54(6), 1183-1206.

Creswell, J. W. (2014). Research design: Qualitative, quantitative, and mixed methods approaches $\left(4^{\text {th }} \mathrm{ed}\right.$.). California: SAGE Publications.

Damiani, M., Pompei, F., \& Ricci, A. (2016). Approach performance related pay, productivity and wages in Italy: A quantile regression approach. International Journal of Manpower, 37(2), 344-371.

Dansereau, F., Graen, G. \& Haga, W. J. (1975). A vertical dyad linkage approach to leadership within formal organization: A longitudinal investigation of the role making process. Organizational Behavior and Human Performance, 13(1), 46-78.

Fauzan, M. F. (2018). A study on effect of leadership styles on employees performance in local courier company: The case study of Pos Laju in Malaysia. Journal of Public Value and Administration Insight, 1(1), 14-20.

Galanaki, E. (2019). Effects of employee benefits on affective and continuance commitment during times of crisis. International Journal of Manpower, 41(2), 220-238.

Hair, J. F., Hult, G. T. M., Ringle, C. M., \& Sarstedt, M. (2017). A primer on partial least squares structural equation modeling (PLS-SEM) $\left(2^{\text {nd }}\right.$ ed.). Thousand Oaks: SAGE Publications Inc.

Harada, J. (2019). Pay reform in the 1990s and slow-burn career development process in Japan. Journal of The Open University of Japan, 36, 71-78. 
Hasniza, H. (2018, July 13). UPUS sokong naik gaji posmen. Sinar Harian online. Retrieved from http://www.sinarharian.com.my/edisi/selang or-k1/upus-sokong-naik-gaji-posmen-1.856091

Heffernan, M., \& Dundon, T. (2016). Cross-level effects of high-performance work systems (HPWS) and employee well-being: The mediating effect of organisational justice. Human Resource Management Journal, 26(2), 211-231.

Henseler, J., Ringle, C. M., \& Sinkovics, R. (2009). The use of partial least squares path modeling in international marketing. Advances in International Marketing, 20, 277-319.

Holmvall, C. M., Stevens, S., \& Chestnut, N. (2019). The impact of subordinate disrespect on leader justice. Personnel Review, 48(1), 2-20.

Indahyati, N., \& Sintaasih, D. K. (2019). The relationship between organizational justice with job satisfaction and organizational citizenship behavior. International Research Journal of Management, IT and Social Sciences, 6(2), 63-71.

Islami, X., Mulolli, E., \& Mustafa, N. (2018). Using Management by Objectives as a performance appraisal tool for employee satisfaction. Future Business Journal, 4(1), 94-108.

Ismail, A. (2020). Performance-based pay: An empirical study in Malaysian Federal Government linked companies, Kuching, Sarawak. Malaysian Management Journal, 12(1-2), 89-101.

Ismail, A., Mashkuri, A. H., Sulaiman, A. Z., \& Hock, W. K. (2014). Interactional justice as a mediator of the relationship between pay for performance and job satisfaction. Intangible Capital, 7(2), 213-235.

Jami' iaturochmah, S., Sudjadi, A., \& Anggraeni, A. I. (2019). The role of organizational commitment in influence of justice toward employee performance (Study at the animal husbandry training center-Batu Ministry of Agriculture). ICORE, 5(1), 383-394. 
Jaros, S. (2007). Meyer and Allen model of organizational commitment: Measurement issues. The Icfai Journal of Organizational Behavior 6(4), 7-25.

Jean, K. N., Ngui, T. K., \& Robert, A. (2017). Effect of compensation strategies on employee performance: A case study of Mombasa Cement Limited. International Journal of Innovative Social Sciences \& Humanities Research, 5(3), 25-42.

Kato, T., \& Kodama, N. (2015). Performance-related Pay and Productivity: Evidence from Japan. Research Institute of Economy, Trade \& Industry. RIETI Discussion Paper 15-E-088. Retrieved from https://www.rieti. go.jp/jp/publications/dp/15 e088.pdf

Kepes, S., Delery, J., \& Gupta, N. (2009). Contingencies in the effects of pay range on organizational effectiveness. Personnel Psychology, 62(3), 497-531.

Khan, H., \& Khan, R. A. (2017). Impact of human resource management practices on employee job satisfaction at Meezan Bank Limited, Karachi. Business Administration and Management Sciences, 2(1), 195-204.

Korir, I., \& Kipkebut, D. (2016). The effect of reward management on employees commitment in the Universities in Nakuru County-Kenya. Journal of Human Resource Management, 4(4), 37-48.

Lee, H., \& Chui, J. (2019). The mediating effect of interactional justice on human resource practices and organizational support in a healthcare organization. Journal of Organizational Effectiveness: People and Performance, 6(2), 129-144.

Levi, N. N., Philip, O. O., \& Ikechukwu, D. (2018). Reward system as a predictor of employees motivation in National Root Crop Institute, Umudike. International Journal of Economics and Business Management, 4(3), 11-20.

Liggans, G., Attoh, P. A., Gong, T., Chase, T., Russell, M. B., \& Clark, P. W. (2019). Military veterans in federal agencies: Organizational 
inclusion, human resource practices, and trust in leadership as predictors of organizational commitment. Public Personnel Management, 48(3), 413-437.

Lomand, T. C. (2016). Social science research: A cross section of journal articles for discussion \& evaluation. London: Routledge.

Mabaso, C. M., \& Dlamini, B. I. (2018). Total rewards and its effects on organisational commitment in higher education institutions. SA Journal of Human Resource Management, 16(1), 1-8.

Maqsood, A., Hanif, R., Rehman, G., \& Glenn, W. (2012). Validation of the three-component model of organizational commitment questionnaire. FWU Journal of Social Science, 6(2), 135-145.

Marasi, S. A. (2014). Pay communication: An overview, scale development and analysis of its influence on workplace deviance. Louisiana: Louisiana Tech University.

Marasi, S., Wall, A., \& Bennett, R. J. (2018). Pay openness movement: Is it merited? Does it influence more desirable employee outcomes than pay secrecy?. Organization Management Journal, 15(2), 58-77.

Martocchio, J. J. (2016). Strategic compensation: A human resource management approach ( $8^{\text {th }}$ ed.). Boston, US: Pearson Education Limited.

Mayes, B. T., Finney, T. G., Johnson, T. W., Shen, J., \& Yi, L. (2017). The effect of human resource practices on perceived organizational support in the People's Republic of China. The International Journal of Human Resource Management, 28(9), 1261-1290.

Messersmith, J. G., Kim, K. Y., \& Patel, P. C. (2018). Pulling in different directions? Exploring the relationship between vertical pay dispersion and high-performance work systems. Human Resource Management, $57(1), 127-143$.

Mylona, E., \& Mihail, D. (2019). Enhancing employees' work performance through organizational justice in the context of financial crisis. A 
study of the Greek public sector. International Journal of Public Administration, 42(6), 509-519.

Načinović Braje, I., Klindžić, M., \& Galetić, L. (2019). The role of individual variable pay in a collectivistic culture society: An evaluation. Economic Research, 32(1), 1352-1372.

Newman, J. M., Gerhart, B. \& Milkovich, G. T. (2017). Compensation (12 ${ }^{\text {th }}$ ed.). New York, NY: McGraw-Hill International.

Nguyen, T. H., \& Tu, V. B. (2020). Social responsibility, organizational commitment, and organizational performance: Food processing enterprises in the Mekong River Delta. Journal of Asian Finance, Economics, and Business, 7(2), 309-316.

Novarini, N. N. A., \& Imbayani, I. G. A. (2019). The influence of reward and punishment on employee performance at Royal Tunjung Bali Hotel \& Spa Legian. International Journal of Applied Business and International Management, 4(3), 33-44.

Odoardi, C., Battistelli, A., Montani, F., \& Peiró, J. M. (2019). Affective commitment, participative leadership, and employee innovation: A multilevel investigation. Journal of Work and Organizational Psychology, 35(2), 103-113.

Oke, A. E., Ibironke, O. T., \& Bayegun, O. A. (2017). Appraisal of reward packages in construction firms. Journal of Engineering, Design and Technology, 15(6), 722-737.

Paoline, E. A., Lambert, E. G., Hogan, N. L., \& Keena, L. D. (2018). The effects of the workplace on jail staff: The issue of perceptions of pay fairness. Corrections, 3(3), 203-224.

Priya, M. R., \& Sudhamathi, S. (2019). Strategies for sustaining the organizational culture and its dimensions. Advance and Innovative Research, 6(2), 219-221. 
Rajaratnam, S. D. (2020). Direct and indirect influence of HRM practices on employee performance and turnover intention. Malaysian Management Journal, 11(1-2), 27-47.

Roth, L. M. (2006). Because I'm worth it? Understanding inequality in a performance-based pay system. Sociological Inquiry, 76(1), 116-139.

Saleem, M. A., Yaseen, A., \& Zahra, S. (2018). Predictors of organizational commitment in public sector hospitals of Pakistan - A moderated mediation study. Journal of Health Management, 20(2), 206-225.

Santos, A. R. (2020). Organizational commitment of instructors of private colleges in Nueva Ecija. Journal of Humanities and Education Development, 2(1), 57-60.

Sekaran, U. \& Bougie, R. (2016). Research methods for business: A skill building approach (7th ed.). New York: John Wiley \& Sons, Inc.

Setiawati, T., \& Ariani, I. D. (2020). Influence of performance appraisal fairness and job satisfaction through commitment on job performance. Review of Integrative Business and Economics Research, 9(3), 133-151.

Simpson, R., Kumra, S., Lewis, P., \& Rumens, N. (2020). Towards a performative understanding of deservingness: Merit, gender and the BBC pay dispute. Gender, Work \& Organization, 27(2), 181-197.

Song, Z., Gu, Q., \& Cooke, F. L. (2020). The effects of high-involvement work systems and shared leadership on team creativity: A multilevel investigation. Human Resource Management, 59(2), 201-213.

Sufian, A., \& Lee, C. C. (2019). Enhancing organizational performance: An investigation of the impact of employees' commitment. International Journal of Human and Technology Interaction, 3(2), 81-88.

Sungu, L. J., Weng, Q., Hu, E., Kitule, J. A., \& Fang, Q. (2020). How does organizational commitment relate to job performance? A conservation of resource perspective. Human Performance, 33(1), 52-69. 
Vajda, É. (2019). Perceived justice as a crucial factor of performance management systems. Vezetéstudomány-Budapest Management Review, 50(5), 25-37.

Van Dijke, M., Leunissen, J. M., Wildschut, T., \& Sedikides, C. (2019). Nostalgia promotes intrinsic motivation and effort in the presence of low interactional justice. Organizational Behavior and Human Decision Processes, 150, 46-61.

Yusuf, F. A. (2020). The effect of organizational culture on lecturers' organizational commitment in private universities in Indonesia. International Journal of Higher Education, 9(2), 16-24.

Zhao, X., Lynch Jr., J. G. \& Chen, Q. (2010). Reconsidering Baron and Kenny: Myths and truths about mediation analysis. Journal of Consumer Research, 37(2), 197-206. 